University of Denver

Digital Commons @ DU

Sturm College of Law: Faculty Scholarship

University of Denver Sturm College of Law

1991

The Economics of Discrimination: The Three Fallacies of Croson

Martin J. Katz

Follow this and additional works at: https://digitalcommons.du.edu/law_facpub

Part of the Civil Rights and Discrimination Commons, and the Legal Remedies Commons 


\section{The Economics of Discrimination: The Three Fallacies of Croson}

\section{Publication Statement}

Originally published as Martin J. Katz, The Economics of Discrimination: The Three Fallacies of Croson, 100 YALE L.J. 1033 (1991). Copyright is held by the author. User is responsible for all copyright compliance. 


\title{
The Economics of Discrimination:
}

\section{The Three Fallacies of Croson $^{1}$}

\author{
Martin J. Katz
}

INTRODUCTION: NO FAULT, NO REMEDY

In City of Richmond v. JA. Croson Co. the Supreme Court held that, in the absence of "identified discrimination," race-conscious affirmative action is impermissible. ${ }^{2}$ Discrimination cannot be "identified," however, by references to severe statistical disparities between the composition of the labor market and that of the general population. ${ }^{3}$ Nor can it be "identified" by reference to "amorphous claim[s]" of past discrimination. ${ }^{4}$ Rather, a showing of "identified discrimination" must "approach[] a prima facie case of a constitutional or statutory violation" by someone in the market. ${ }^{5}$ Such proof must point to an overt or implied act of illegal, race-conscious decisionmaking. ${ }^{6}$

Yet those who have been injured in a market by illegal, race-conscious decisionmaking generally have a remedy in antidiscrimination law. ${ }^{7}$ Thus the question remains: what remedies are available to those who have been harmed by discrimination but have no remedy under antidiscrimination law-i.e.,

1. City of Richmond v. J.A. Croson Co., 488 U.S. 469 (1989).

2. Specifically, the Court held that Richmond's construction "set-aside" program, which it characterized as an "unyielding racial quota," was impermissible in the absence of "identified discrimination." Id. at 499, 505. Croson did not address the permissibility, absent "identified discrimination," of non-numerical raceconscious programs, as opposed to quotas. (Non-numerical programs do not reserve a fixed number or percentage of positions for minority group members, but merely grant these members a "plus" in the selection process for those positions. See, e.g., Regents of the Univ. of Cal. v. Bakke, 438 U.S. 265, 317 (1978).) "Plus" plans and quotas, however, are analytically similar, even though they may remain legally distinct. Id at 379 (Brennan, J., dissenting). Thus, this Note will not distinguish between explicitly numerical and non-numerical race-conscious affirmative action.

3. Croson, 488 U.S. at 501.

4. Id. at $498-99$.

5. Id. at 500 .

6. Id. at 498-500. The Court will accept as proof of "identified discrimination" a statistical comparison showing a significant disparity between the pool of "qualified" minorities and those who have successfully entered the market. Id. at 501-02. Where qualified minorities are failing to enter the market in the same proportion as similarly qualified nonminorities, the implication is that someone must be actively keeping them out of the market-i.e., discriminating.

7. See, e.g., Albemarle Paper Co. v. Moody, 422 U.S. 405, 418 (1975) ("It is . . . the purpose of [antidiscrimination laws] to make persons whole for injuries suffered on account of unlawful employment discrimination."); Franks v. Bowman Transp. Co., 424 U.S. 747, 763 (1976) (aff' g Albemarle); see also Civil Rights Act of 1964 , Title VII, $\S 706(\mathrm{~g}), 42$ U.S.C. $\$ 2000 \mathrm{e}-5(\mathrm{~g})$ (1988) (granting courts broad equitable power to fashion remedies for victims of unlawful discrimination). 


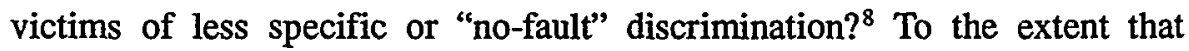
Croson's "identified discrimination" standard excludes "no-fault" discrimination, it places race-conscious remedies beyond the reach of these victims."

When a party to litigation ${ }^{10}$ asserts that she has been injured and prays for a given form of relief, a court can deny such relief on any of three grounds. The court may:

1. Deny that any injury has occurred;

2. Prescribe a remedy which is preferable to the relief prayed for by the injured party, or;

3. Deny the relief prayed for on the grounds that it is, in some sense, worse than the injury.

The Croson Court makes all three of these arguments. ${ }^{11}$ First, the Court suggests that racial asymmetries in the market do not necessarily represent an injury to excluded minority group members. Second, it proposes that this exclusion can be remedied through race-neutral policy. And third, it argues that

8. By "no-fault" discrimination, I do not mean that no party was ever at fault. Rather, I use the term to refer to the effects of past discrimination which are beyond the reach of a fault-based system of antidiscrimination law. An act of discrimination may be unremediable under antidiscrimination law for any number of reasons: the perpetrator may be unidentifiable, long dead, or unable to compensate her victim. If many perpetrators were involved, it may be difficult to isolate responsibility for any particular discriminatory effect. Additionally, an act of discrimination may have been legal when it was committed. I discuss the concept of no-fault discrimination in greater detail in Current Topic, Insurance and the Limits of Rational Discrimination, 8 YALE L. \& POL'Y REV. 436, 445-47 (1989). Because time figures so prominently in this type of injury, I will also use the term "intertemporal discrimination" to describe this concept.

Though I will focus on "no-fault" discrimination in this Note, I assume that any remedy for "no-fault" discrimination will operate against the backdrop of-and as a compliment to-the fault-based system. The efficacy of any particular fault-based system of antidiscrimination laws, however, is beyond the scope of this Note.

9. But cf. Joint Statement, Constitutional Scholars' Statement on Affirmative Action After City of Richmond v. J.A. Croson Co., 98 YALE L.J. 1711 (1989) (suggesting that invalidation of Richmond's program might be limited to facts of Croson).

10. The Black subcontractors in Croson were not technically parties to this litigation. They had requested their remedy from the City of Richmond. The City granted this remedy and was challenged in Croson. By denying the City's right to grant a race-conscious remedy, however, the Court effectively denied these contractors this remedy. Thus, for the purposes of this Note, I will treat these Black contractors as if they had applied to the Court for race-conscious relief and been denied. Indeed, the Court in Croson seems to analyze the issue in this way. See, e.g., 488 U.S. at 505 (discussion of Black subcontractors' claims of injury and appropriate remedy).

11. Two additional arguments might be made for refusing to grant a given remedy. First, the remedy might be per se unconstitutional even if it is desirable as a matter of social policy. The Court, however, clearly endorses the use of race-conscious affirmative action where discrimination can be "identified," $i d$. at 504-05, implying that this remedy is not per se unconstitutional. Second, the Court might arguably deny a remedy where the same remedy may be granted by another authority such as Congress. Id. at 504 (suggesting that Congress, under section five of 14th Amendment, can adopt set-aside to remedy non"identified" discrimination); see also Metro Broadcasting, Inc. v. FCC, 110 S. Ct. 2997 (1990) (upholding congressional set-aside program without "identified" discrimination); Fullilove v. Klutznick, 448 U.S. 448 (1980) (same). The fact that a coordinate branch may find a given remedy constitutionally permissible, however, hardly justifies a court's finding to the contrary. 
a race-conscious program to benefit victims of no-fault discrimination is likely to be overinclusive, creating a "moral hazard" for minority group members and placing an unfair burden on nonminority competitors.

An economic analysis of these arguments, however, shows that they are all flawed. In Part I, this Note examines the effects of discrimination in the marketplace to suggest a connection between current racial disparities ${ }^{12}$ and past "no-fault" discrimination. Part II demonstrates why race-neutral policies are likely to prove ineffective for reducing these disparities. Finally, Part III argues that competitive, race-conscious affirmative action is unlikely to create a "moral hazard" and that the burden placed on nonminorities by such a program is justifiable.

\section{The Significance of RACIAL Disparities}

Fallacy \#1:

[It is] "completely unrealistic" [to assume] that minorities, [in the absence of discrimination], will choose a particular trade in lockstep proportion to their representation in the local population. ${ }^{13}$

The City of Richmond offered, as proof of discriminatory injury, statistics showing a marked disparity between Blacks' representation in the local population and their participation in the local construction industry. ${ }^{14}$ The Croson Court, however, refused to infer the existence of discrimination, and hence an injury, from such a disparity. ${ }^{15}$ Such disparities, the Court argues, might result from phenomena other than discrimination; Blacks, for example, might simply choose to work in other fields. ${ }^{16}$

Yet it is not clear whether racial disparities in a lucrative market like construction contracting ${ }^{17}$ can be explained adequately without reference to discrimination. Can racial asymmetries appear and persist in a labor market ${ }^{18}$

12. I will concentrate on race discrimination in this Note, specifically race discrimination against Blacks, for the sake of simplicity and because of the significance of this form of discrimination to the Croson decision. The analysis, however, should be equally applicable to discrimination on the basis of sex and against racial minorities other than Blacks.

13. Croson, 488 U.S. at 507 (citing Sheet Metal Workers v EEOC, 478 U.S. 421,494 (1986) ( $O$ 'Connor, J., concurring in part and dissenting in part)).

14. Id. at $479-80(0.67 \%$ of city contracting dollars going to minority contractors in community which is $50 \%$ Black).

15. Id. at 501 .

16. Id. at 503 .

17. The average hourly earnings in the construction industry exceeded the average hourly earnings in all private sector occupations by an average of $52.35 \%$ between 1960 and 1988 . Construction wages were higher in each of these years, with differences ranging from $64.93 \%$ (in 1971) to $41.01 \%$ (in 1988). BUREAU OF LABOR STATISTICS, U.S. DEP'T OF LABOR, BULL. NO. 2340, HANDBOOK OF LABOR STATISTICS 312 (1989).

18. Analytically, an entrepreneurial market such as construction contracting can be considered a labor market. Just as a worker sells her labor to buyers of labor services (i.e., employers), an entrepreneur sells 
absent discrimination? An economic model will prove useful in trying to answer this economic question.

The following sections will introduce an economic model commonly used to analyze behavior in labor markets: the competitive equilibrium model. ${ }^{19}$ This model explains how discrimination yields racial asymmetries in labor markets where monopoly power is present. Additionally, the model suggests that discrimination in related markets causes racial asymmetries, even in competitive primary markets. The basic model, however, has difficulty explaining the persistence of these asymmetries in markets that are subject to antidiscrimination law. When the basic model is combined with an intertemporal view of discrimination, however, it can explain how racial disparities might persist as a result of past discrimination, even in competitive markets, and even after the imposition of effective antidiscrimination law. The expanded model is then applied to assess the Court's contention that racial disparities in labor markets might be explained by nondiscriminatory factors such as "choice."

\section{A. Discrimination and Racial Disparities: The Basic Model}

The competitive equilibrium model makes four basic assumptions: ${ }^{20}$

1. Equal productivity-that there are no systematic differences in productivity between racial groups. ${ }^{21}$

2. Equal rationality-that workers will recognize and pursue all opportunities that would increase their total utility (i.e., make them better off).

3. Profit maximization - that employers will make decisions so as to maximize business profits.

her services to buyers of entrepreneurial services. Because "employers" serves as a useful shorthand for "buyers of entrepreneurial services," and because it is the context in which most labor market analysis has been done, I will commence my analysis using an employer-employee paradigm.

19. Joseph Stiglitz explains the use of this term:

The focus on equilibrium is not that the [market] is always in equilibrium, but (as in other areas of economic analysis) to ascertain whether there are market forces tending to equalize any differential treatment. The emphasis on competitive markets is based on the belief that [it will be difficult for rival employers to cooperate in conspiring against Black workers]. The analyses do not, however, require perfect competition in the product markets.

Stiglitz, Approaches to the Economics of Discrimination, AM. ECON. REV., May 1973, at 287, 288 n.2. For a good summary of this model see R. LIPSEY \& P. STEINER, ECONOMICS 355-61, 368-76 (6th ed. 1981).

20. Clearly these assumptions-tantamount to assuming a "perfect market"-are, to some extent, unrealistic. The point of the analysis, however, is to determine which assumptions fail to hold in which markets and why. As long as the assumptions are approximated in some markets, econometric techniques can test the validity of the model by comparing markets where a given assumption holds with those in which it does not hold. See, e.g., infra note 29 and accompanying text.

21. Productivity is the value of the contribution that a worker makes to the production process. 
4. Competition-that firms compete for both:

a. market share in the product market, and

b. workers in the labor market.

In such a market, employers will hire any worker whose productivity equals or exceeds the wage which she must be paid.22 Workers will be drawn to those occupations and jobs where they can realize maximum returns on their productivity. If two equally productive pools of workers are equally drawn to various occupations, then applications for those positions should be roughly proportionate to the relative size of the two populations. If competitive employers maximize profits by offering employment opportunities based on productivity, then equally qualified workers should apply for and obtain those jobs with equal frequency. Thus, as long as the assumptions are valid, the representation of each race in the work force, or of any employer within such an industry, should approximate its representation in the general population.

Discrimination by employers might cause racial disparities in the labor market. An employer might discriminate against Blacks, paying them a reduced wage relative to whites or refusing to hire Blacks at any wage. ${ }^{23}$ Blacks working for this employer will earn a lower return on their productivity than whites and, hence, will apply for fewer of these jobs. The employer's workforce will become racially skewed. As more employers discriminate, racial disparities in the labor market will become more marked.

This type of discrimination by employers, however, could only occur in markets where competition is less than perfect. If the labor market is competitive, discrimination by employers will not maximize profits (Assumption 3); ${ }^{24}$ and if Assumption 4a (competitive products market) is correct, any non-profitmaximizing producer will be forced out of business. If employer $D$ pays white workers more than Black workers (or refuses to hire Black workers whose productivity exceeds their wage), these actions will directly increase $D$ 's costs of production relative to those of any non- (or less-) discriminatory employer, $N$. Consequently, $N$ will be able to sell her products for less than $D$, while still covering her costs of production. $D$ will lose market share to $N$ and eventually be forced out of business (or be forced to refrain from discriminating). ${ }^{25}$

22. An alternative formulation states that each worker will be paid a salary equal to her productivity. Theoretically, the lower limit of a wage offer is constrained only by what a worker will accept for her time, based on her "opportunity cost" (the amount she could earn in an alternative position). In practice, however, wage reductions are often limited by minimum wage laws or collective bargaining agreements. For this reason, I will focus on hire/no-hire decisions rather than wage decisions.

23. Note that a refusal to hire Blacks at any wage is tantamount to offering zero wages to Black workers.

24. I assume, for the moment, that average productivity does not differ between the races. The possibility that employers might maximize profits by reacting to racial differences in productivity-the possibility of "rational discrimination"-will be addressed infra at Sections I.B-C.

25. See G. BECKER, THE ECONOMICS OF DISCRIMINATION 44-45 (2d ed. 1971). This point is explained less technically in K. ARROW, Models of Job Discrimination, in 6 COLLECTED PAPERS OF KENNETH J. ARROW 89, 97-98 (1985), and in LIPSEY \& STEINER, supra note 19, at 369-73. 
Discrimination, and hence racial disparities, might persist in markets where competition is flawed. An employer with monopoly power in the market for her product can charge a price greater than her cost, earning economic profit. She can thus sacrifice some of her profits to indulge a "taste for discrimination." ${ }^{26}$ Consumer information costs, ${ }^{27}$ brand loyalty, and other barriers to entry can protect such a producer's monopoly power against encroachment from competitors. ${ }^{28}$ Discrimination might also occur where an employer has monopsony power (a buyer's monopoly) in the labor market. Minimum wage laws and high employee information costs often impair competition in labor markets, creating a pool of unemployed workers. An employer can indulge in racial preferences with economic impunity when choosing from such a pool.

Yet the fact that lapses in competition might permit discriminatory acts, and hence yield racial disparities, cannot explain the persistence of such disparities in several highly competitive markets. ${ }^{29}$ Government intervention, discrimination in related markets, or the existence of certain types of "demand" for racism, however, might cause racial disparities even in competitive markets. Jim Crow laws (or the threat of extralegal racist action) may prohibit the hiring of Blacks. Monopolistic suppliers of materials (including financing, insurance, and education) may discriminate, refusing to sell to employers who hire Blacks (or to Black employers), or may charge them a price premium. ${ }^{30}$ Consumers

But cf. Riedesel, Racial Discrimination and White Economic Benefits, 60 Soc. SCI. Q. 120, 126-28 (1979) (white employers gain from discrimination because they can pay Black workers lower wages than would be possible without discrimination). While Riedesel sees Blacks being paid underpaid, however, Arrow notes that a discriminatory employer will also overpay whites. K. ARRow, supra, at 94 . To the extent that an employer can find a Black who can do the same job at a lower price than a white, Arrow's economic reasoning is correct: the white is overpaid.

26. This term was coined by G. BECKER, supra note 25 , at 14 .

27. Arrow attempted to explain the existence of racial asymmetries in markets as a result of producer (rather than consumer) information costs. K. ARRow, supra note 25 , at 105 . He suggested that where the cost of obtaining pre-hiring information on workers' productivity is high, employers might rationally act on their preconceptions about productivity (e.g., that Blacks' productivity is lower than that of whites)even where such preconceptions are inaccurate. Id. at 105-06. To the extent that there is perfect competition in the related product market, however, such an employer will not be able survive in the market. Her costs will be higher because the total productivity of her workers will be lower than that of her nondiscriminatory competitors.

28. Governments generally enjoy a high degree of monopoly power in the markets for their products (e.g., the markets for government buildings, parks, streets, etc.). If a government's costs become too high, it may get voted out of office. Short of this sanction, however, governments enjoy wide latitule in the prices they can charge for their products and, hence, in the prices they can pay for their inputs such as labor. The potential for discriminatory behavior by government employers is therefore high absent antidiscrimination laws that raise the cost of discriminating.

29. See, e.g., Marshall, The Economics of Racial Discrimination: A Survey, 12 J. ECON. LIT. 849,863 (1974) (racial disparity in competitive textiles industry in South).

30. Another important source of supplier discrimination may be discrimination by unions or trade associations. Unions, trade associations and referral services effectively control entry into several of the building trades. These groups often manage apprenticeship and training programs as well as direct a substantial portion of work to various members. Such organizations, however, have often been vocal opponents of racial integration; many have been notorious for attempting any possible circumvention of antidiscrimination laws. This form of discrimination, according to economists, has been one of the major factors contributing to the tremendous racial asymmetries that have long persisted in the building trades. See Hammerman, Minorities in Construction Referral Unions, MONTHLY LAB. REV., May 1972, at 17, 21 
may be willing to pay more for white-made products; or white workers may be willing to accept a cut in pay to work in an all-white work environment. ${ }^{31}$ Any of these forms of discrimination will raise the cost of hiring Blacks, so that a profit-maximizing employer will prefer to hire whites.

As explanations of current racial disparities, however, these forms of discrimination seem unconvincing. Jim Crow regimes, presumably, are a thing of the past. Racist consumers and co-workers, to the extent that they currently exist in numbers sufficient to have a significant impact, confront enormous economic pressures. ${ }^{32}$ Further, discrimination by employers, suppliers and unions generally violates antidiscrimination laws.

The basic competitive equilibrium model suggests that once these discriminatory forces cease, the racial composition of the labor market should approach that of the population. Assuming that these forms of discrimination have ceased, how can racial disparities like that in Richmond's contracting industry persist?

\section{B. An Intertemporal Approach to Discrimination}

An intertemporal view of discrimination allows the competitive equilibrium model to explain the persistence of racial disparities in any market, irrespective of the degree of competition or the prevalence of current racism in related markets. In this view, any act of discrimination continues to affect its victim's productivity beyond the time when the act has ceased. As long as Blacks' productivity is lower than that of whites, employers will prefer whites. ${ }^{33}$ Hence in any market where discrimination was prevalent in the past, current racial disparities might be explained in terms of that discrimination. A cost

(increased minority participation in union would drastically increase minority participation in market representation); see also Gould, Racial Discrimination, the Courts, and Construction, INDUS. REL., Oct. 1972 , at 380,389-90 (suggesting need for legal assault on discriminatory trade union practices). The Croson Court acknowledged that this form of discrimination might be at least partially responsible for certain labor market asymmetries. 488 U.S. at 503-04.

31. Racist white workers in a competitive market cannot demand a wage premium for working with Blacks. A profit-maximizing employer would simply hire an all-Black workforce.

32. Markets in which consumers know the race of the workers who made a product are more the exception than the rule. K. ARROW, supra note 25, at 95-96. As for white co-workers, long-run competitive pressures make the formation of all-white firms difficult. Id. at 102. In general, arguments suggesting the sacrifice of income by either consumers or co-workers do not account for "those vast forces of greed ... [which] are the mainsprings of economic activity ...; not the best but the strongest motives of humanity ...." Id. at 97 .

33. This is the concept of "rational discrimination." In this paradigm, employers do not consciously discriminate on the basis of race; i.e., they do not "intentionally" discriminate. Rather, they discriminate only according to productivity, which may happen to correlate with race. See infra note 39 and subsequent text. For an explanation of the relationship between "intentional" and "rational" discrimination, see Current Topic, supra note 8 , at $436-37$ n.4. 
structure analysi ${ }^{34}$ suggests why an intertemporal view of discrimination is compelling.

The likelihood of success in an entrepreneurial market ${ }^{35}$ depends largely on the costs faced by a potential entrant. Anyone who produces a good at a cost which is greater than her competitors' must sell that good at a higher price. Accordingly, fewer buyers will be willing to buy her goods. ${ }^{36}$ In this sense, cost may be seen as analogous to productivity; both are measures of attractiveness to buyers and, hence, of the likelihood of successfully finding a buyer for one's goods or services.

Entrepreneurial cost can be envisioned as a curve which starts high and becomes lower over time, approaching a minimum (the lowest cost possible given current technology) (Figure 1). ${ }^{37}$

\section{Figure 1. Entrepreneurial Cost}

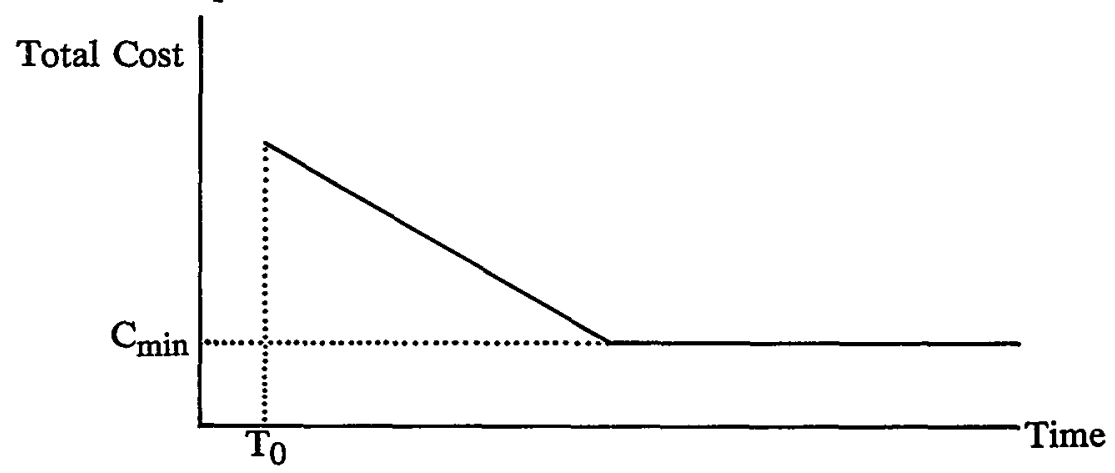

34. Cost structure arguments are not novel in the area of discrimination. Many authors point to barriers to entry which appear to be linked to past racism and which prevent minorities from entering lucrative occupations such as construction contracting. See, e.g., Rosenfeld, Decoding Richmond: Affirmative Action and the Meaning of Constitutional Equality, 87 MICH. L. REV. 1729, 1767 (1989) ("some blacks lack the requisite qualifications to become successful entrepreneurs in the construction industry ... because they have been victims of systematic . . . racial discrimination"); Note, The Nonperpetuation of Discrimination in Public Contracting: A Justification for State and Local Minority Business Set-Asides after Wygant, 101 HARV. L. REV. 1797, 1807 (1988) (highlighting several economic barriers that prevent entry by Blacks into construction industry). None of these authors, however, attempts to exhaust other possible explanations for disparate entry. Nor do they detail the causal link between past discrimination and present barriers to entry to illustrate why race-conscious action is both necessary to break this link and morally sound as to nonminority competitors.

35. The effect of past discrimination on cost structure is easier to see in the context of entrepreneurial entities than in individual workers. For this reason, and because of the relevance of entrepreneurial activity to Croson and to economic opportunity, the following analysis will focus on entrepreneurs rather than workers. As suggested supra, at note 18 , the analytical concepts are virtually identical.

36. While a producer might attract buyers to high priced goods by selling "quality" or "reputation," she cannot avoid price competition. Rather, such a producer merely competes with other producers of "high quality" or "trustworthy" goods.

37. The illustrations that follow will use a "kinked," rather than an asymptotic, function in order to increase the clarity of presentation. 
Costs start high for two reasons. First, a new entrant usually must cover several costs of entry. ${ }^{38}$ These are the expenses that must be paid prior to doing business, including education expenses, licensing fees, and the cost of the tools and premises necessary for production.

In addition to covering her entry costs, a new entrant will generally face relatively high costs of operation. Her lack of experience may make her less efficient than a more seasoned competitor. Also, several of her necessary inputs, such as credit, bonding, and insurance, will be more expensive (if she can obtain these inputs at any price) until she has developed a track record which establishes her as "lower risk". Further, a new entrant lacks the important element of name recognition; this increases the difficulty and, hence, the cost of both finding work and attracting employees. Name recognition is particularly important in a relations-intensive market, such as that for subcontractors, where prime contractors prefer to hire a subcontractor whom they know and trust over a less expensive but unknown subcontractor.

Because cost is an intertemporal concept, anything which affects cost is likely to have intertemporal effects. This is particularly clear in the case of discrimination. Assume that a white entrant, $W$, and a Black entrant, $B$, both start at time $\mathrm{T}_{0}$ with identical cost curves. If $B$ is discriminated against, her cost curve will be pushed up or out relative to $W$ 's.

If entry is barred for Blacks, ${ }^{39} B$ 's entry costs will be infinite. Eventually the bar may be removed (at time $T_{1}$ ) and $B$ will be able to enter the market, but she will enter with a higher cost than that at which $W$ then produces (Figure 2). For example, $B$ might face costs in terms of low efficiency and name recognition which $W$ has already put behind her. At $\mathrm{T}_{1}, B$ will produce at the cost at which $W$ initially produced, at $T_{0}$. Effectively, $B$ 's cost curve (the broken line, below) has been pushed out relative to $W$ 's. ${ }^{40}$

38. Financing may effectively convert entry costs into operating costs. For example, instead of paying for her education or tools all at once, at $T_{0}$, an entrant might pay for them over several years. Thus, at $T_{0}$ her cost will fall by the amount financed. Thereafter, for the duration of the loan, her cost will rise by the amount of her loan payments (plus interest).

39. A discriminatory bar might be caused by slavery, a Jim Crow regime, or an entry qualification such as education, if Blacks have been systematically denied access to that qualification.

40. Note that the effect of a discriminatory bar is virtually identical to the effect of $B$ 's simply deciding to enter the market later than $W$. These are the obstacles faced by any new entrant to the market. My concern, however, is not with late entry itself, but with late entry which is a result of racial discrimination. This concern, of course, begs the question of how to distinguish between Blacks who have entered the market late as a result of discrimination and those who have entered late as a matter of choice. As will be demonstrated infra, in Section I.C, however, choice must be considered in the context of incentives; it is difficult to explain group differences in entry time as a result of choice, absent discrimination. Further, as demonstrated infra, in Part III, as long as the remedy is competitively allocated, it is likely to identify those individuals whose prospects for entry-and hence whose choices-were influenced most by discrimination. 


\section{Figure 2. Effect of Discriminatory Bar on Entry Costs}

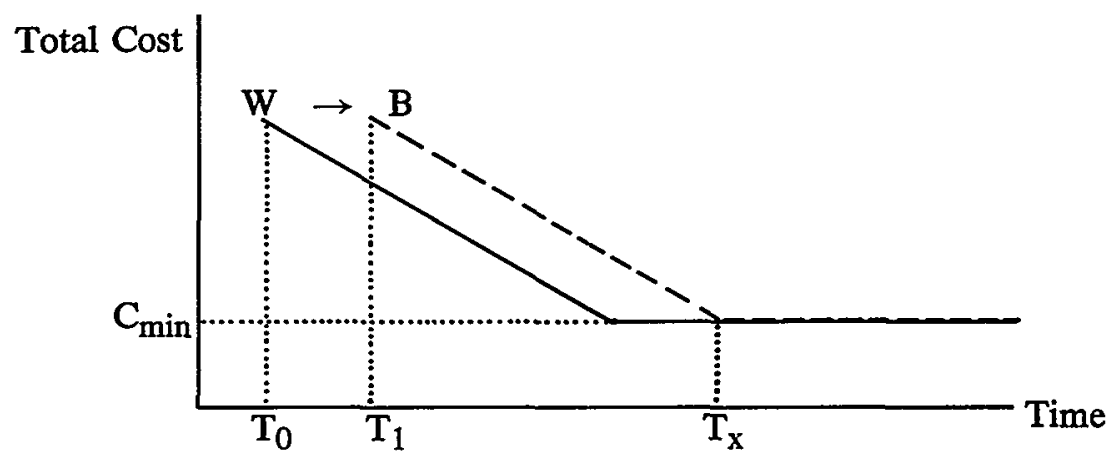

Similarly, discrimination other than an absolute bar will raise $B$ 's production costs above $W$ 's. If racist suppliers charge a premium to Black buyers, for example, $B$ 's costs will rise over $W$ 's; $B$ 's curve will be pushed up (Figure 3 ).

\section{Figure 3. Effect of Discrimination on Production Costs}

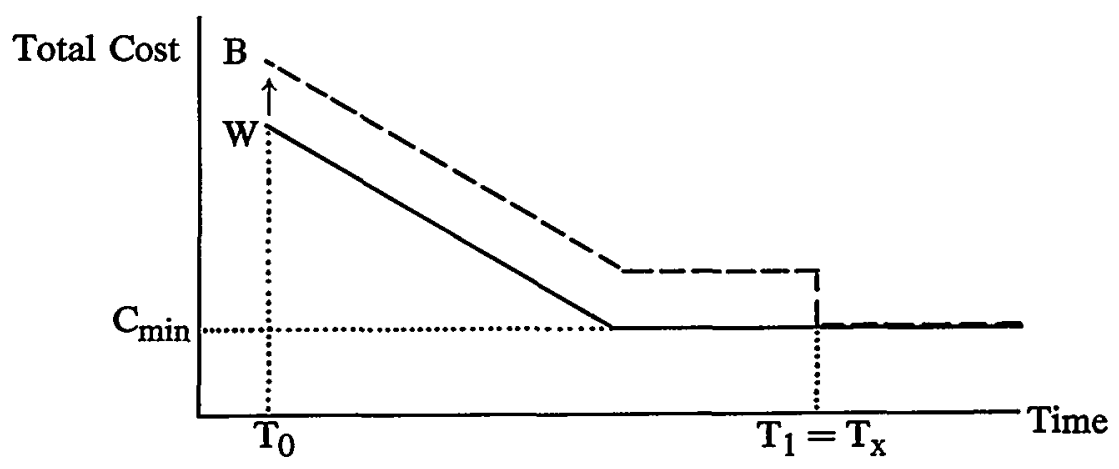

It might appear that once discriminatory acts cease, $B$ 's curve will eventually reach the same level as $W$ 's; that $W$ 's curve will flatten out at the technological minimum, allowing $B$ 's curve to "catch up" at time $\mathrm{T}_{\mathrm{x}}{ }^{41}$ The time value of money, however, effectively prevents such catching up. From $T_{0}$ until $\mathrm{T}_{\mathrm{x}}, W$ had lower costs than $B$ and, hence, earned more revenue. By investing this excess revenue, $W$ can effectively keep her cost curve perpetually below $B$ 's. ${ }^{42} B$ will face a persistent competitive disadvantage.

41. Note that if technology continues to improve, so that $\mathrm{C}_{\min }$ moves continually downward, then $W$ 's cost curve may continue to fall and B's may never "catch up."

42. The concept of investment of excess revenue requires some caveats. $W$ will reinvest this excess revenue wherever it yields the highest rate of return. Thus, she might reinvest in her firm, if doing so will reduce her technological minimum cost, $C_{\min }$. In this case, her cost curve will remain below $B$ 's curve in a literal sense. Alternatively, this revenue might draw a higher rate of return if invested elsewhere, for example in a certificate of deposit (CD). Arguably, $W$ might use the interest earned on her $C D$ to "crosssubsidize" her production costs, effectively (though "artificially") keeping her cost curve below $B$ 's. Empirically, this practice (also known as "predation," since it allows $W$ to charge a lower price than $B$ while still covering her production costs), appears to be rare. See R. POSNER, ECONOMIC ANALYSIS OF LAW 285 
In fact, there is no reason to expect that $B$ 's relative disadvantage will subside even upon her retirement or death. Financial advantage-and hence disadvantage - is transferable across generations. If $B$ 's heirs and $W$ 's heirs each inherit their mothers' businesses, they will likely face cost curves similar to those of their parents. $B$ 's daughter will thus face a higher cost curve than $W$ 's daughter. Alternatively, the parents may simply liquidate their businesses, passing on the proceeds to their heirs. In this case, W's daughter will receive funds which $B$ 's daughter does not, making capital formation in any new business less costly; in any new business, $W$ 's daughter will start with an advantage in cost over $B$ 's daughter. ${ }^{43}$

Cost structure analysis thus suggests that discrimination is likely to result in racial cost disparities which can persist long after the discrimination has ceased. The competitive equilibrium model shows how racial cost disparities-essentially disparities in productivity-can explain disparities in participation in virtually any market. This analysis provides a clear conceptual link between present racial disparities in markets and past discrimination. It lends credence to the claim that the racial disparity in Richmond's contracting industry implies a discriminatory injury to Blacks. The question remains, however, whether such a disparity can be explained without reference to discrimination.

\section{Disparities without Discrimination}

The Croson Court attempts such an explanation: the "dearth of minority participation" in Richmond's construction industry might have resulted from "black and white career and entrepreneurial choices." 44 Within the competitive

(3d ed. 1986). In a capital-intensive market such as construction contracting, however, cross-subsidization may make particular sense: it will almost always be cheaper to "lend" money to oneself than to borrow it (because monitoring costs are eliminated). I am indebted, for this point, to Akhil Reed Amar.

If $W$ does not use the return from her $C D$ to cross-subsidize her contracting business, $B$ 's cost curve will eventually "catch up" to $W$ 's. The question remains, however: what opportunities does $W$ have as a result of this return that $B$ has been denied as a result of discrimination? The issue of the general economic impact of discrimination on Blacks, as opposed to its impact on Blacks' prospects in a specific market, is the subject of B. BITTKER, THE CASE FOR BLACK REPARATIONS (1973).

43. Research into the effects of initial asset distribution on relative group incomes supports this reasoning. DeCanio, Accumulation and Discrimination in the Postbellum South, in MARKET INSTITUTIONS AND ECONOMIC PROGRESS IN THE NEW SOUTH 1865-1900, at 103, 125 (G. Walton \& J. Shepherd eds. 1981) (even under optimal economic conditions and in absence of postbellum discrimination, Blacks would nevertheless face substantial income gap for extremely long time as result of being emancipated without any property - having been denied all property rights as slaves). This problem may be compounded by apparent difficulties in Black families of transmitting any gains that are made to subsequent generations. See Dachter, RacelSex Differences in the Effects of Background on Achievement, in 9 FIVE THOUSAND AMERICAN FAMILIES-PATTERNS OF ECONOMIC PROGRESS 359, 359 (M. Hill, D. Hill \& J. Morgan eds. 1981) (Black heredity-ability to pass on family economic gains-appears to be less effective than white heredity).

44. Croson, 488 U.S. at 503 . Such theories have been suggested by some economists as well. See, e.g., T. SOWELL, The Sears Case, in COMPASSION VERSUS GUILT 149, 151 (1987) ("Nowhere do [groups of] people have the same preferences, behavior, or performance . . . . Hispanic American college students do not choose the same mixture of subjects to major in as Asian Americans, . . . or whites the same subjects 
equilibrium framework, however, such choices could only be explained in one of two ways. Either Blacks must be less rational than whites (a relaxation of Assumption 2), or their incentives must differ from those of whites. An assertion of disparate rationality would be both racist and without any evidentiary basis; ${ }^{45}$ it seems unlikely that the Court could mean this. ${ }^{46}$ Yet, the suggestion that Blacks and whites have different incentives to enter the construction contracting market begs the question: why?

The Court suggests that Blacks might be disproportionately attracted to another market. "Relative to the distribution of all businesses, black-owned businesses are more than proportionately represented in the transportation industry, but considerably less than proportionately represented in the wholesale trade, manufacturing, and finance industries." ${ }^{\prime 47}$ The question remains: why? Why might Blacks continue to be disproportionately "attracted" to lower paying industries like transportation over lucrative ones like construction? ${ }^{48}$ There appears to be no evidence of racial variation in preferences for monetary, as opposed to non-monetary, compensation. ${ }^{49}$ Such "choices" simply make no sense unless Blacks enjoy being poor-or unless there are race-based barriers to entry into the construction contracting market. ${ }^{50}$

Thus, economic analysis suggests that past "no-fault" discrimination provides the best explanation for current racial disparities in markets; that such

as blacks.").

A close variant of choice theories, also championed by Sowell, are "cultural," or "attitudinal" theories. See, e.g., T. SOWELL, ETHNIC AMERICA 284 (1981) (attitudes, including those related to "absenteeism, tardiness, and a need for constant supervision" get passed on through "cultural inheritance"; result in different economic success rates between groups). Alternatively, some minority groups might disproportionately inherit skills, such as those involved in cooking an indigenous cuisine. Cultural inheritance theories, however, like choice theories, beg the question: assuming that there are no differences between groups in either intelligence or utility for money, what might cause one group to make choices or develop cultural traits that make its members systematically less well off than members of other groups?

45. Cf. Kahneman \& Tversky, Prospect Theory: An Analysis of Decision Under Risk, 47 EconOMETRICA 263 (1979) (in cognitive theory of decisionmaking, no suggestion of racial disparity in decisionmaking skills); Machina, Choice Under Uncertainty: Problems Solved and Unsolved, 1 J. EcoN. PERSP. 121 (1987) (extensive review of literature updating Kahneman \& Tversky theory uncovers no suggestion of racial disparity in decisionmaking skills).

46. "[I]n the eye of the law, there is . . no superior, dominant . . class of citizens." Plessy v. Ferguson, 163 U.S. 537, 559 (1896) (Harlan, J., dissenting).

47. Croson, 488 U.S. at 503 (quoting The State of Small Business: A Report of the President Transmitted to the Congress 201 (1986)).

48. The average hourly earnings in the construction industry exceeded those in the transportation and public utility industries by an average of $19.32 \%$ between 1964 and 1988 . Construction wages were higher in each of these years; differences varied from $36.10 \%$ (in 1970) to 5.60\% (in 1988). BUREAU OF LABOR STATISTICS, supra note 17, at 312; see also Gould, supra note 30, at 389 (wage rates high in construction industry).

49. But $c f$. T. SOWELL, RACE AND ECONOMICS (1975) (Blacks might seek non-monetary gains, e.g., leisure time, community, etc.; thus might prefer job with low monetary compensation but high utility). We live in a society, however, where utility seems closely tied to money. There appears to be no evidence suggesting racial variation in income-utility preferences.

50. As suggested above, discrimination reduces incentives to enter a market. See supra text following note 23 . Thus, where one market contains discrimination and a second market does not, Blacks may have incentives to enter the second market, even if it is less lucrative. Thus, discrimination increases Blacks' incentives to enter inferior markets, explaining their overrepresentation in these markets. 
disparities should be seen as a manifestation of discriminatory injury. The Court provides no convincing alternative explanation for these disparities.

\section{THE INEFFicaCy OF RACE-NEUTRAL POLICY}

Fallacy \#2:

If [minority firms] disproportionately lack capital or cannot meet bonding requirements, a race-neutral program of city financing for small firms would, a fortiori, lead to greater minority participation. $^{51}$

To the extent that racial disparities in a market represent an injury, Croson suggests-and in most cases mandates-an alternative remedy to race-conscious affirmative action: race-neutral policy ${ }^{52}$ Helping all aspiring entrants or all small businesses would be examples of race-neutral policy. Yet cost structure analysis shows that race-neutral policy is likely to be ineffective in remedying the injury of discriminatory exclusion from a competitive labor market.

The use of race-neutral affirmative action to encourage market entry, and thereby remedy the injury of discrimination, is based on what might be called a "trickle in" theory. There exists a pool of people outside the market who aspire to enter it, but who, given their present cost structure, cannot do so. If, however, the cost structure that these people face were to become more favorable-either through reduction or subsidization of entry costs ${ }^{53}$ - some members of this pool would enter. To the extent that entry is random, and that the pool is composed largely of those injured by discrimination (Blacks), trickle in theory posits that those victims should trickle into the market.

The problem with trickle in theory-and with race-neutral affirmative action-is that it envisions a homogenous pool, from which entry will be random. Yet a ranked pool is more realistic. An entry model illustrates this ranking and its implications.

Two elements of this entry model derive from cost structure analysis: First, any potential entrepreneur can be seen as facing a set of costs which can be characterized as a cost curve or cost structure. Second, the prospects for successful entry into a market such as construction contracting will depend on the position of that cost structure relative to other competitors' cost structures.

51. Croson, 488 U.S. at 507.

52. Id. (inefficacy of race-neutral policy prerequisite to use of race-conscious policy).

53. Lowering the formal requirements for entry into the market, such as those of certification or bonding, could reduce entry costs. Yet it is often difficult to isolate costs which are distinctly related to entry. A reduction in bonding requirements, for example, would benefit firms that have already entered the market as well as those contemplating entry. Such a distribution of benefits might be desirable, however, if the goal is not only to encourage entry but also to ensure the continued viability of new entrants. 
Thus, envision a queue of all potential entrepreneurs, ranked according to their cost structures, from lowest cost to highest cost (Figure 4). ${ }^{54}$

\section{Figure 4. The Entry Queue}

\begin{tabular}{|c|c|c|c|c|c|c|c|c|c|c|c|}
\hline \multicolumn{12}{|c|}{ Entry } \\
\hline $\begin{array}{l}\# \\
12\end{array}$ & $\begin{array}{l}\# \\
11\end{array}$ & $\begin{array}{l}\# \\
10\end{array}$ & $\begin{array}{c}\# \\
9\end{array}$ & $\begin{array}{l}\# \\
8\end{array}$ & $\begin{array}{l}\# \\
7\end{array}$ & $\begin{array}{l}\# \\
6\end{array}$ & $\begin{array}{c}\# \\
5\end{array}$ & $\begin{array}{c}\# \\
4\end{array}$ & $\begin{array}{c}\# \\
3\end{array}$ & $\begin{array}{c}\# \\
2\end{array}$ & $\begin{array}{c}\# \\
1\end{array}$ \\
\hline
\end{tabular}

High Cost

Low Cost

The entrepreneur whose costs are lowest $\left(\#_{1}\right)$ will have the best prospects for successful entry; the one whose costs are highest $\left(\#_{12}\right)$ will have the worst prospects. Depending on the size of the relevant market, an "entry threshold" will exist somewhere in the queue..$^{55}$ Above that threshold, all of the potential entrepreneurs will be able to enter the market; below it, they will remain aspirants, unable to enter unless the market expands.

A government may help aspirants enter-help them cross the entry threshold-in one of two ways. First, it can attempt to move the threshold, through policies designed to expand the market, so that those on the top of the aspirant pool can enter. Alternatively, the government can target certain members of the aspirant pool (other than those in the top segment) to receive a "leg up" over their fellow competitors, allowing them to rise in the queue to a point where successful entry is possible (beyond the entry threshold). ${ }^{56}$

The first tactic, market expansion, is clearly "race-neutral." It seeks to help "top aspirants," rather than Blacks. If this program is to act as a remedy for intertemporal discrimination, however, it is not likely to work. Intertemporal discrimination, after all, increases its victims' cost curves; it pushes its victims down in the queue of potential entrants. Thus, it is unlikely that those victims will be heavily represented at the top of the aspirant pool.

Of course, if the market expansion is sufficiently large, then a large segment of the pool may enter. If this remedy extends far enough down in the pool, eventually those who have been pushed to the bottom by discrimination will be helped - but only after many non-Black aspirants, those who have benefitted

54. Figures 4 through 7 first appeared in my Current Topic, supra note 8, at 448-50.

55. The position of the entry threshold (i.e., the size of the market in terms of the number of firms it can accommodate) will depend on the strength of consumer demand and the capacity of firms in the market.

56. Most policies to expand a market attempt to increase demand. This can be accomplished either directly, through government purchasing, or indirectly, through subsidization. If producers are subsidized they can produce at a reduced cost and, hence, at a reduced price. At this reduced price, demand for their product will increase.

Note that a policy which subsidizes only a specific group of producers, rather than all producers, will have both "leg up" and market expansion effects. 
from discrimination, have also been helped.$^{57}$ Further, as more people enter the market, the market share that any one entrant can capture becomes smaller. Eventually, as the cumulative ranks of the aspirant pool are helped to enter, the market share captured by each will become so small that it becomes extremely unlikely that the entrants from the bottom of the pool will be able to remain in the market once the helping hand is removed.

Contrast this situation with one in which only a limited number of potential entrants are targeted for help to enter the market (e.g., the top Black applicants). Those helped will receive a competitive "leg up" on unaided members of the aspirant pool, as well as on marginal entrants in the market. Because other competitors are not also being helped, the amount of aid necessary to give this "leg up" to targeted entrants will be relatively small. Simply by virtue of being in the market and gaining production experience (and name recognition), a target firm should increase its efficiency. Where the amount of aid given to such firms is not too great, these efficiency gains should offset costs from the eventual withdrawal of aid, allowing the firm to remain competitive in the market.

Thus, in a competitive market, where the aspirant pool is ranked with respect to productivity, helping hand policies are likely to be ineffective unless they are limited to a specific target group. Yet such a policy clearly begs the question of whom to include in the target group. If target group definition is overinclusive within the aspirant pool ("small businesses," for example, is a categorization likely to include the whole pool), the policy will help no one. If, however, the target group is fashioned to maximize the benefit received by those who have requested a remedy-victims of racial discrimination - it will not be a race-neutral remedy. Victims of racial discrimination, after all, are by definition members of a specific race. ${ }^{58}$ To the extent that a facially neutral definition of the target group (e.g., "living in a distressed, inner-city area") successfully singles out members of this racial group, such a definition would be a mere "smokescreen"- $a$ thin cover for race-conscious policy. ${ }^{59}$

In summary, race-neutral affirmative action-the alternative remedy suggested by the Croson Court-is unlikely to be effective in reducing disparities in cost structure and, hence, market representation that have resulted from discrim-

57. For an empirical analysis of whites' gains from discrimination, see Riedesel, supra note 25, at 126 28. For a theoretical analysis of these gains, see infra Part III.

58. Of course, discrimination and its lingering disadvantaging effects have not been limited to Blacks. Clearly, individualized programs could be fashioned for each group that can show that it was victimized by "no-fault" discrimination. Alternatively, a city might merge these programs into a generic "minority" aid program for purposes of administrative simplicity. Although such a merger would avoid the political problems inherent in explicitly allocating aid among disadvantaged groups, it might invite a de facto allocation to more competitive-often less disadvantaged-groups.

It is beyond the scope of this Note to try to identify all of these groups or to set a standard of proof by which a group might establish its status as discriminatorily disadvantaged.

59. This is not to say that smokescreens are necessarily without value. See, e.g., G. CALABRESI, A COMMON LAW FOR THE AGE OF STATUTES 178 (1982) (discussing merits of obscuring value choices). For purposes of this Note, however, I will take the Court's opinion at face value. 
ination. A competitive, race-conscious remedy, however, similar to that rejected by the Court, is likely to be effective. ${ }^{60}$ Yet Croson seems prepared to limit the use of race-conscious policy to situations where acts of discrimination can be identified (and where race-neutral policy has already proven ineffective) ${ }^{61}$ Thus, to the extent that "identified discrimination" excludes victims of intertemporal discriminatory injuries, ${ }^{62}$ these victims are likely to be left without an effective remedy.

\section{THE FAIRNESS OF COMPETITTVE, RACE-CONSCIOUS REMEDIES}

Fallacy \#3:

[R]acial characteristics ... seldom provide a relevant basis for disparate treatment . . . and are potentially . . . harmful to the entire body politic ....63

Even if racial disproportion in the market represents a discriminatory injury, and even if race-conscious affirmative action is the only efficacious method of remedying that injury, the Court might reasonably make such a remedy unavailable where it considers that remedy worse, in some sense, than the injury.

Croson suggests that race-conscious affirmative action is problematic for a number of reasons. First, the Court suggests that such a remedy is likely to skew incentives, promoting gamesmanship rather than industry among entrepreneurs. ${ }^{64}$ Second, it proposes that such programs are likely to be overinclusive; that they will help people who were not injured by and hurt people who received no benefit from discrimination. ${ }^{65}$ Finally, the Court argues that such a program violates fundamental principles of individuality by distinguishing among individuals on the basis of irrelevant characteristics. ${ }^{66}$

An extension of the foregoing entry analysis, however, suggests that none of these arguments is convincing. The queue of potential market entrants can be divided into two parallel queues: a Black queue and a white queue. This analysis allows an examination of the likely incidence of benefits, burdens, and

60. Compare Croson, 488 U.S. at 550 (Marshall, J., dissenting) (citing Fullilove v. Klutznick, 448 U.S. 448 (1980)) (race-neutral measures "discredited by Congress as ineffectual in eradicating the effects of past discrimination in [contracting] industry") with Leonard, What was Affirmative Action?, AM. ECON. REV., May 1986, at 359 (race-conscious measures effective in increasing Black share of contracting market).

61. Croson, 488 U.S. at 505, 507-08. Croson's requirement that race-neutral steps be tried prior to adopting a race-conscious program, despite the fact that such preliminary steps are likely to prove fruitless, amounts to a commandment to waste resources. This waste will directly affect the quantity of resources remaining to implement-and hence the eventual effectiveness of-any subsequent race-conscious plan.

62. See supra note 9 and accompanying text.

63. Croson, 488 U.S. at 505.

64. Id. at 489 (O'Connor, J., concurring) (citing Fullilove v. Klutznick, 448 U.S. 448, 488 (1980)) (expressing fear that minority businesses will exploit program).

65. Id. at 515-16 (Stevens, J., concurring).

66. Id. at 505 . 
incentives from a competitive, race-conscious remedial program. This expanded entry model demonstrates that such a program would maintain market incentives for efficiency, avoid the pitfalls of overinclusiveness, and enhance respect for individuality.

A race-conscious program targets potential entrants in the Black queue to receive benefits. As long as these benefits are competitively allocated among Black potential entrants, incentives toward efficiency will be preserved. A competitive allocation, such as a "set-aside,"67 assures that only those at the top of the Black queue will receive these benefits. To be at the top of this queue, one must be more efficient (i.e., have lower costs) than one's fellow competitors. Hence, the Court's worries about inefficiency or "moral hazard" are unfounded.

The question remains, however, whether those minority contractors who are helped by such a program - those at the top of the Black queue-are those most deserving of a remedy. ${ }^{68}$ By hypothesis, they are not likely to be the neediest among the minority group. Yet the goal, or at least the primary goal, of raceconscious affirmative action is not a welfare goal; it is a remedial goal. Thus the question is better put: is a set-aside likely to help those who have been hurt most by intertemporal discrimination? Conversely, are those who will bear the greatest burden of such a program likely to be the benefactors of this discrimination? The expanded (two-queue) entry model suggests an affirmative answer to both of these questions.

The expanded entry model illustrates the intertemporal effects of discrimination and the impact of the proposed remedy. Competitive equilibrium theory suggests that, prior to discrimination, the two parallel queues of potential entrants (the white queue and the Black queue) should be similarly placed relative to the entry threshold (Figure 5).

Figure 5. The Market before Discrimination

\begin{tabular}{|c|c|c|c|c|c|}
\hline \multirow{2}{*}{$\begin{array}{l}\text { Aspirants } \\
\text { Whites }\end{array}$} & \multicolumn{5}{|c|}{$\begin{array}{l}\text { Entry } \\
\text { Threshold }\end{array}$} \\
\hline & $\begin{array}{l}* \\
6\end{array}$ & $\begin{array}{l}* \\
5\end{array}$ & $\begin{array}{l}* \\
4\end{array}$ & $\begin{array}{l}* \\
3\end{array}$ & $\begin{array}{l}* \\
2\end{array}$ \\
\hline Blacks & $\begin{array}{l}+ \\
6\end{array}$ & $\begin{array}{l}+ \\
5\end{array}$ & $\begin{array}{l}+ \\
4\end{array}$ & $\begin{array}{l}+ \\
3\end{array}$ & $\begin{array}{l}+ \\
2\end{array}$ \\
\hline
\end{tabular}

67. A "set-aside" program reserves a certain portion of available positions or contracts for target group members. These positions or contracts are allocated competitively among the target group members; they are granted to the "most qualified" (i.e., lowest cost, thus lowest bidding) members of that group.

68. It has been suggested that the Court, in remedying specific acts of discrimination, has often permitted an imperfect correlation between those affected by discrimination and those who are most affected by the Court's remedy. Sullivan, The Sins of Discrimination: Last Term's Affirmative Action Cases, 100 HARV. L. REV. 78-80 (1986). 
That is, for any given market size, a proportionate number of Blacks and whites should fill the available positions. Cost structure analysis, however, suggests that discrimination pushes the Black queue back, relative to the white queue; that it systematically raises Blacks' cost curves (Figure 6).

\section{Figure 6. The Market after Discrimination}

\begin{tabular}{|c|c|c|c|c|c|c|c|c|c|c|c|}
\hline \multicolumn{12}{|c|}{ Entry } \\
\hline $\begin{array}{l}\text { Aspirants } \\
\text { Whites }\end{array}$ & & & & & $\begin{array}{l}* \\
6\end{array}$ & $\begin{array}{l}* \\
5\end{array}$ & $\begin{array}{l}* \\
4\end{array}$ & $\begin{array}{l}* \\
3\end{array}$ & $\begin{array}{l}* \\
2\end{array}$ & 1 & Entrants \\
\hline Blacks & $\frac{+}{6}$ & $\begin{array}{l}+ \\
5\end{array}$ & $\begin{array}{l}+ \\
4\end{array}$ & $\begin{array}{l}+ \\
3\end{array}$ & $\begin{array}{l}+ \\
2\end{array}$ & $\begin{array}{c}+ \\
1\end{array}$ & & & & & \\
\hline
\end{tabular}

Thus, the Blacks who would have been the marginal Black entrants $\left(B_{3}\right.$ and $\left.B_{2}\right)$ will find themselves on the other side of the entry threshold-unsuccessful aspirants. Similarly, the whites who, prior to discrimination, were the marginal aspirants $\left(W_{4}\right.$ and $\left.W_{5}\right)$ will find themselves able to enter. These marginal entrepreneurs are those most affected by discrimination.

A competitively allocated race-conscious program benefits current marginal Black aspirants and burdens current marginal white entrants. A "set-aside" is a good example of such a program. An effective set-aside increases the number of contracts available to Blacks, reducing the number of contracts available to whites by this amount. Thus, it effectively lowers Blacks' cost curves, relative to those of whites; ${ }^{69}$ it pushes the Black queue forward, relative to the white one (Figure 7).

Figure 7. The Market after a Set-aside

Aspirants

Whites

Blacks

\begin{tabular}{cccc|cccc}
\multicolumn{10}{c}{ Entry } \\
\multicolumn{10}{c}{ Threshold } \\
& $\leftarrow$ & $*$ & $*$ & $*$ & $*$ & $*$ & $*$ \\
& 6 & 5 & 4 & 3 & 2 & 1 \\
+ & + & + & + & + & + & & \\
6 & 5 & 4 & 3 & 2 & 1 & $\rightarrow$
\end{tabular}

Entrants

69. A set-aside effectively tells the top Black aspirant, $B_{2}$ : "Whatever the difference is between your cost and that of the marginal white entrant, $W_{5}$, the government will cover it. That is, even though you charge more than $W_{5}$, the government will buy from you, rather than from her." This formulation, of course, assumes that the only obstacle to $B_{2}$ 's providing the same quality of product as $W_{S}$ is cost. In the short run $B_{2}$ may face qualification obstacles, such as insufficient training or experience. These obstacles involve time, as well as cost. Depending on the government's needs and priorities, however, it might be willing to incur some costs of waiting as well as the monetary costs of the set-aside. 
As a result, the marginal Black aspirant $\left(B_{2}\right)$ will be able to enter the market successfully. ${ }^{70}$ Because the number of positions in the market is limited, however, the marginal white entrant $\left(W_{5}\right)$ will find herself pushed out of the market by the set-aside (into aspirant status).

Thus, a race-conscious set-aside affects the appropriate parties. ${ }^{71}$ It would only be overinclusive if it shifted the queues back past the point of equality-so that the Black queue was pushed ahead of the white one. This is unlikely as long as the proportion of contracts set aside is equal to or less than the proportion of Blacks in the population. Recall that the competitive equilibrium model suggests that there is no reason why, once the effects of discrimination were eliminated, the two queues would not be positioned equally. ${ }^{72}$

The Court, however, appears to eschew such conceptions of group justice. It suggests that treating individuals as members of a group "stigmatizes" them; ${ }^{73}$ and expresses a fear "that race will always be relevant in American life, and that the 'ultimate goal' of 'eliminat[ing] entirely from governmental decisionmaking such irrelevant factors as a human being's race' . . . will never

70. A Black contractor who is comfortably above the entry threshold (e.g., $B_{1}$ ) may win a contract which was included in the set-aside. Such a contractor, however, will then have less capacity available to take other contracts, leaving these for the next best competitor. This next best contractor will then free up work which will be taken by her closest rival, and so on. Thus, all Black contractors will gain the difference in value between the contract won as a result of the set-aside and best work they were doing previously. For the one on the margin, however, this is the difference between success and failure in the market. Similarly, while a contract that is set aside may be lost by a supramarginal white contractor, its effects will be felt most strongly at the margin.

71. Arguably, while $W_{5}$ might be an appropriate bearer of the burdens of a set-aside, she might not be the "best" bearer of these costs because she is "innocent"; she has not been accused of engaging in any discriminatory act. The point of a no-fault system, however, is not to punish but to spread costs-the costs of remedying "no-fault" discrimination. For an analysis of the desirability of such government spreading see Current Topic, supra note 8, at 445-47. As to incentives, a set-aside does not preclude the use of antidiscrimination laws to punish those who cause discriminatory injuries; it is intended to operate as a complement to those laws.

72. See supra Part I.

Two caveats should be noted here. First, competing policy considerations might argue for a set-aside less than the proportion of Blacks in the population. See, e.g., Croson, 488 U.S. at 477,479 (30\% set-aside relative to Richmond's $50 \%$ Black population). For example, a set-aside that significantly exceeded the capacity of Blacks with some minimal qualifications to perform the contracts would be grossly inefficient. See supra note 69. A policy maker might therefore need to balance equality and efficiency considerations. She might, for example, choose the proportion of funds to be set aside for minority firms to approximate or slightly exceed the current and expected short-term capacity of qualified Black firms. Such a compromise might leave some Blacks who have been injured by discrimination without a remedy (e.g., $B_{3}$ in Figure 7). While such a policy may be underinclusive, however, the above analysis suggests that the Court's fears of overinclusiveness are exaggerated. (Additionally, because the size of the set-aside under such a compromise would be tied to measurable values-the relative size of the population and the available capacity of minority entrepreneurs-the Court's worries about arbitrariness would be addressed. See Croson, 488 U.S. at 507.)

Second, this analysis, it may be noted, assumes that discrimination has affected all members of each group equally; that all whites have benefitted equally from discrimination and that all Blacks have been equally injured by it. It is possible that discrimination has affected ranking within the queues as well as between them, implicating the fairness of helping the marginal Black and hurting the marginal white. No evidence, however, appears to suggest such an intragroup impact from discrimination.

73. Croson, 488 U.S. at 516 (Stevens, J., concurring). 
be achieved." 74 To the extent that race is relevant because it has been made relevant by discrimination, however, acting as if it were irrelevant is not only incongruous, it will ensure that race will continue to be relevant. As suggested above, without the availability of a race-conscious remedy, racial differentials in cost, and hence in market participation, are likely to persist.

To the extent that the injury of past discrimination is allowed to persist unremedied because its "cause" cannot be specifically identified and documented, individuality is compromised: whites will be allowed to retain an advantage which they did not earn, and Blacks will continue to lag behind as a result of acts which, although they may not be amenable to documentation, no one denies were performed in contempt of individuality. Racism has made race relevant to productivity. Treating race as if it were irrelevant will not help to make it any less relevant.

\section{CONCLUSION}

This Note has argued that the Court should permit the use of competitive, race-conscious affirmative action to remedy the continuing effects of past discrimination. Economic analysis of Croson's arguments against such a remedy suggests that these arguments are, at best, problematic. This analysis explains current racial disparities as a product of past acts of discrimination; the Court's explanation that those excluded may not have been injured is economically untenable. The analysis suggests why the Court's prescription of a race-neutral remedy is unlikely to alleviate economic exclusion; why race-conscious action is necessary to alleviate the injury of economic exclusion. Unless affirmative race-conscious steps are taken to counter this exclusion, it is likely to persist in undermining both individuality and merit in our markets and in our society.

74. Id. at 495 (quoting Wygant v. Jackson Bd. of Educ., 476 U.S. 267, 320 (1986)). 